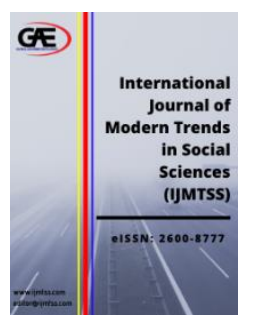

International Journal of Modern Trends in Social Sciences (IJMTSS)

Journal Website: http://ijmtss.com/ eISSN: $2600-8777$

\title{
FACTORS INFLUENCING YOUNG FEMALE PURCHASE INTENTION TOWARDS LOCAL COSMETICS PRODUCT IN MALAYSIA
}

\author{
Nik Noorhazila Nik Mud ${ }^{1}$, Norfazlirda Hairani ${ }^{2}$, Aimi Nadia Ibrahim@ Zakaria ${ }^{3}$, Mardhiah \\ Kamaruddin $^{4}$, Hazriah Hasan ${ }^{5}$
}

1 Faculty of Entrepreneurship and Business, Universiti Malaysia Kelantan (UMK), Malaysia Email: noorhazila.nm@umk.edu.my

2 Faculty of Entrepreneurship and Business, Universiti Malaysia Kelantan (UMK), Malaysia Email: fazlirda.h@umk.edu.my

3 Faculty of Entrepreneurship and Business, Universiti Malaysia Kelantan (UMK), Malaysia Email: aiminadia.i@umk.edu.my

$4 \quad$ Faculty of Entrepreneurship and Business, Universiti Malaysia Kelantan (UMK), Malaysia Email: mardhiah.k@umk.edu.my

5 Faculty of Entrepreneurship and Business, Universiti Malaysia Kelantan (UMK), Malaysia Email: hazriah.h@umk.edu.my

\section{Article Info:}

\section{Article history:}

Received date:24.12.2019

Revised date: 13.01 .2020

Accepted date: 16.01.2020

Published date: 15.03.2020

\section{To cite this document:}

Nik Mud, N. N., Hairani, N., Ibrahim@Zakaria, $\quad$ A. N., Kamaruddin, M., \& Hasan, H. (2020). Factors Influencing Young Female Purchase Intention towards Local Cosmetics Product in Malaysia. International Journal of Modern Trends in Social Sciences, 3 (11), 0112.

DOI: $10.35631 /$ IJMTSS.311001.

\begin{abstract}
:
This paper aimed to study the effect between attitude, brand awareness, consumer experiences and price on young female purchase intention towards local cosmetic products in Malaysia. The main factor of consumer behaviour that used in this study was to analyse customer female purchase intention were attitude, brand awareness, consumer experience, and price. We used a survey questionnaire to collect 226 valid responses from a female student of Bachelor of Entrepreneurship (Retailing) with Honours in UMK. These collected data were analysed using Statistical Package for Social Science (SPSS) version 24 and the result gathered through the Pearson Correlation Coefficient and Multiple Regression. The findings revealed that attitude, brand awareness, consumer experiences, and price emerged with a significant influence on female intention toward local cosmetics among young female consumers. The implication from this study is for the female consumer who is wearing a cosmetic product, an industry or organization who involve in produce local cosmetic product and retailer who sale a local cosmetic product. Finally, the result shows that attitude influences young female purchase intention the most compared to brand awareness, consumer experiences, and price.
\end{abstract}

Keywords:

Attitude, Brand Awareness, Consumer Experience, Price, Female Purchase Intention 


\section{Introduction}

Understanding the purchase intention of female towards local cosmetic products helps a local organization or business to fulfil consumer need and want. Cosmetics and personal care product have long been present. This product is used daily by many people and its use is increasing every year. The use of this product is regarded as a requirement for personal hygiene, better appeal, skin and hair protection from ultraviolet light and harmful contaminants and slowing down the aging process. Due to advances in technology, the cosmetics industry is constantly looking for new and effective products that are available, cheap and secure. At the same time, information on the identity and source of ingredients used in cosmetics is not always available; therefore verification of the validity and acceptance of the materials may be require (Hashim \& Mat Hashim, 2013). The cosmetics industry has grown rapidly in both developed and developing countries. The cosmetics market in Asia seems to be one of the fastest growing markets. According to the Association of Southeast Asian Nation (ASEAN), cosmetics can defines as 'any substance or preparation intended to be placed in contact with the outside of the human body or with teeth and membranes of the oral cavity with natural view or especially to clean it, change their appearance and/or correct the smell of the body and/or protect or keep them in good condition (Azmi Hassali, Al-Tamimi S K, 2015). Users should also be willing to pay higher prices for high quality product and good benefits, such as whitening, multifunctional and anti-aging (Azmi Hassali $\mathrm{M}^{*}$ et al., 2015). The appearance of attractive is very important for both man and female. Recently, the people are willing spend a great deal of money to take maintain the beauty of the face and skin by buying a trusted cosmetic.

However, local cosmetics brands are becoming popular when Instagram, Facebook and Twitter start to become the norm in our society. They are mostly founded by fashion entrepreneurs, professional makeup artists and celebrities as well as influential social media. According to the 2016 study on personal care and cosmetics in Malaysia conducted by the US International Trade Administration, while a large number of local manufacturers produce and own their home brands, more local players turn to local cosmetics manufacturers and focus on personal contracts or labelling (Nadia Baharuddin, 2017). The cosmetics industry in Malaysia is growing at an annual rate of $13 \%$. This is due to the increase in the number of female workers, urbanization, and increase self-awareness due to education. The industry is expected to grow rapidly in the future due to the huge demand for premium products (Eze, Tan, \& Yeo, 2012). The Global Beauty Market is usually divided into five major business segments: skin care, hair care, colours (make-up), fragrances and toiletries. These segments are complementary and through them their diversity can satisfy all customer needs and expectations about cosmetics. Beauty products can also be divided into premium and mass production segments, according to brand brands, prices and distribution channels used. In the global view of the mass segment represent $72 \%$ of total sales in 2010 , while the premium segment accounted for the remaining $28 \%$. The majority of global premium cosmetics sales are concentrated in developed markets (Barbalova, 2011).

Based on previous studies, most women do not care about side effects after using a product that promises beauty to the wearer. This statement has been supported by Mansor \& Yaacob (2010) they said that a few of cosmetic consumer were ignoring consumption of product effect to the skin. They also give priority to short-term impact to the skin compared to long-term effect that affects full body. Most of them were not aware whether it good or not to the skin. They also did not check the ingredient of the product before deciding. A few products put scientific term in ingredient which caused difficult consumer to understand the content and material meaning (Norudin, M., Desnika, MA., Rafi, 2010). 
Thus, this study attempts to fill up this gap by examine factors of consumer behaviour (attitude, brand awareness, consumer experience and price) that influence female purchase intention of local product cosmetics among students of Universiti Malaysia Kelantan, City Campus.

\section{Literature Review}

\section{Theory of Reasoned Action (TRA)}

To determine factors that influence consumer purchase intention theory of reasoned action (TRA) was used (Belleau, Summers, Xu, \& Pinel, 2007). This theory based on the premise that make systematic use of information which available to individuals rationally. This model was designed the relationship between attitude and behaviour. According to the theory of reasoned action (TRA) a person's intention is a function of two basic determinants which one personal in nature and the other reflecting social influence (Lada, Harvey Tanakinjal, \& Amin, 2009).

\section{Purchase Intention}

Purchase intentions can be defined as personal action tendencies according to brand. It is one of the components of consumer cognitive behaviour on how an individual intends to buy a specific brand (Ling, Chai, \& Piew, 2010). Dissimilar perceptions among consumers may lead to different evaluations about products when they want to choose and make a purchase (Rezvani et al., 2012). Besides, word-of-mouth are highly influenced consumers' purchase intentions (Kenyon \& Sen, 2012). However, purchase intention became the most significant issue in industry to improve brand standing in the market and induce a positive feeling among consumers (Borzooei, Mahdi \& Asgari, 2013). It have been used to identify buying likelihoods for products within defined time periods (Whiltar, Geurts, \& Swenson, 1993). Factors that are more likely to influence purchase intention include product type, prior purchase, and, to a lesser extent, gender (Brown, Pope, \& Voges, 2003). Besides, to determine factors that influence consumer purchase intention, theory of reasoned action (TRA) was used (Belleau et al., 2007).

\section{Attitude}

Attitude means feeling, tendencies or reaction on something such as object or idea (T.E.O Yuan Sim et al, 2012). Consumers' attitudes are developed from personal experiences, earning with reality, information from friends and salesperson (L.I.M. Ying San et al, 2012). Some consumers know and understand on every ingredient that used in cosmetic product because they aware of the long-term effect on their skin and also to avoid the risk on the skin and money also. But some consumers were not really care about the long-term effect on the skin. They were just wanting a beauty and light skin in a short period of time without care the on the longterm effect or in the future.

According to Rodda (2004) skin can be more sensitive when consumers use the cosmetic product that might not suit with their skin. Not all consumers have the same skin condition and they have to know the exact products or ingredients in cosmetic product that suit their skin to prevent the risk on the skin. Skin problem also influence consumer purchase intention on cosmetic product especially in female. There are some skin problems such as acne, dry skin, oily skin, white head, black head and dull skin. All of this problem will influence consumer purchase intention because especially carrier female or student.

\section{Brand Awareness}

Aaker (1991) defines brand awareness as the ability of the potential buyer to recognize and recall that a brand is a member of a certain product category. When consumer aware about the 
cosmetic product brand, they will consider the cosmetic product into their purchase list. Another element of brand awareness is brand image. Brand image means, a consumer perception towards particular brand (Keller, 1993). Brand image is used by company to introduce their product as well an image to community. Loudon \& Della Bitta (1988) defines that brand image will influences the way consumer view the products and will lowering purchase risks.

\section{Consumer Experiences}

Customer perceptions of service quality, effectiveness of a product and quality of product will differ either they had walk in or online purchase. They experience decide them to make last decision before making any purchase. Also, choices are based on the other customer experience such as relatives, friends, buddies or even their neighbour picking method for selecting items being factor influence them to choose right cosmetic product. There is an interaction effect between customer experience level and picking method for customer perceptions of service quality. Service quality is correlated with increased customer behavioural intentions. For example, through media social and media electronic, sellers need to be intelligent to attract customer to buy their product. Consumer experience level is difficult to compete with the best advertisement either because they had faced many situations successful and unsuccessful when applying any cosmetic product to their body.

\section{Price}

Price is very important when consumer want to buy a product. If the product expensive, this will affect the consumer interested to buy the product. Price may be the most important consideration in ordinary users. However, the price of a product does not affect the consumer's intent to purchase a product as it does in brand loyalty (Rahim, 2018). Consumer satisfaction can also be constructed by comparing the prices with the costs that it considers and values. It is also one of the strongest indicators of customer loyalty (Singh \& Pattanayak, 2014). If the value of the product viewed is greater than the cost, note that the consumer will purchase the product (Yee \& Sidek, 2008). Consumer will buy cosmetic product if the price is affordable to them.

\section{Methodology}

\section{Population and Sampling}

This study is focus on Retailing (SAR) female student on UMK, City Campus. According to the data from Faculty of Entrepreneurship and Business (FKP), the total number population of female student in UMK City Campus is 3020 students. This study aimed to identify the factors that can influence young female purchase intention towards local cosmetic product among SAR female student in UMK which consists of 544 students. According Krejcie \& Morgan Model (1970) this research required a sample size of 226 respondents in UMK, City Campus. In this study, non-probability which is convenience sampling was been use in this research to determine a sample.

\section{Research Instrument}

The research instrument for this study was used questionnaire as a survey. A structured questionnaire is used to collect the necessary data from respondents. It used as a primary data to answer the research the research questions and objectives. Therefore, Six-Point Likert Scale from 1(Strongly Disagree) to 6(Strongly Agree) were used in this questionnaire. 


\section{Generalization of Items in Questionnaire}

The questionnaire was divided into three sections. Section A will focus on information which includes elements demographic information such as gender, age, race and marital status. Section B is indicating which is find out the factors of consumer behaviour such as attitude, consumer experiences, brand awareness and price that influence female purchase intention. While section $\mathrm{C}$ will more concentrate on the dependent variable which is the purchase intention of the respondents toward local products will use to this study to measure female purchase intention on local product. In these sections, the respondents will be answering the survey question on Six-Point Likert type scale. According to Babakus and Mangold (1992), Devlin et al (1993), Hayes (1992), six-point likert scale is using to less confusing and to increase response rate among respondents.

\section{Summary of Findings}

\section{Reliability of Analysis}

Table 1: Result of Cronbach's Alpha

\begin{tabular}{|l|c|}
\hline Variable & Cronbach's Alpha \\
\hline Dependent Variable: & 0.93 \\
Female Purchase Intention & \\
\hline Independent Variable: & 0.91 \\
Attitude & 0.91 \\
Brand Awareness & 0.96 \\
Consumer Experience & 0.83 \\
Price & \\
\hline
\end{tabular}

Source: (Develop for the Research)

By using a small number of respondents compared to the design sample size, a pilot study is a method used to the questionnaire. In pilot test, the questionnaire was being tested to evaluate the scale reliability through Cronbach's Alpha value. However, 30 target respondents were randomly chosen in order to test the reliability of the questionnaire. Cronbach's alpha is a single test administration to provide a unique estimate of the reliability for a given test and it reliability coefficient normally ranges between 0 and 1 (Gliem \& Gliem, 2003). The average value of Cronbach's Alpha coefficient ranged from 0.70 and beliefs to 0.82 (Peterson, 2013). The value less than 0.6 will be eliminated from the questionnaire. The researchers selected those students who have been purchase local cosmetic product in this pilot study.

\section{Respondents Demographic Characteristic}

Table2: Frequency Output for Respondents Demographic Profile

\begin{tabular}{lrrrrr}
\hline Category & $\mathrm{N}$ & $\%$ & Category & $\mathrm{n}$ & $\%$ \\
\hline Age & & & Occupation & & \\
$18-20$ & 51 & 22.6 & Part time working & 56 & 24.8 \\
$21-23$ & 171 & 75.7 & full time student & 170 & 75.2 \\
$24-26$ & 4 & 1.8 & & &
\end{tabular}


Race

Malay

Chinese

Indian

Others

Status

single

married
181

20

18

7
Years of study

80.1 First year

48

21.2

8.8 second year

69

30.5

8 third year

$45 \quad 19.9$

3.1 fourth year

28.3

\begin{tabular}{crrlrr} 
Status & \multicolumn{5}{l}{ Income } \\
single & 218 & 96.5 & no income & 148 & 65.5 \\
married & 8 & 3.5 & RM1000-below & 64 & 28.3 \\
& & & RM1001-RM2000 & 13 & 5.8 \\
& & & RM 2001-RM3000 & 1 & 0.4 \\
& & & RM3001-RM4000 & 0 & 0 \\
\hline Source: (Develop for the Research) & & & &
\end{tabular}

A complete data was collected with 226 respondents. As presented in Table 2, the majority respondents in 21-23 years old about 171 respondents $(75.7 \%)$ followed by $18-20$ years old was 51 respondents $(22.6 \%)$ and continue with $24-26$ years old was $4(1.8 \%)$. In term of race, the highest respondent is Malay are 181 respondents $(80.1 \%)$. Followed by Chinese are 20 respondents $(8.8 \%)$ and continued by Indian about 18 respondents $(8.0 \%)$. Lastly, the lowest respondent is other race was 7 respondents (3.1\%). In relation to status, single status is dominant which represents about 218 respondents $(96.5 \%)$ and married status are 8 respondents $(3.5 \%)$. From the analyses, the majority respondents are full time students with 170 respondents $(75.2 \%)$ and followed by part time working with 56 respondents $(24.8 \%)$. In the term of years of study, the highest respondent is from second year, 69 respondents $(30.5 \%)$. Followed by fourth year with 64 respondents $(28.3 \%)$ continued with first year, 48 respondents $(21.2 \%)$ and lastly, third year with 45 respondents $(19.9 \%)$. Last demographic profile analyses is income. The highest frequency was the lowest income which is no income with 148 respondents (65.5\%). The second frequency was RM1000 and below with 64 respondents $(28.3 \%)$. Followed by income from RM1001 until RM2000 with 13 respondents (5.8\%) and continued by RM2001 until RM3000 with 1 respondent (0.4\%). Lastly, the income from RM3001 until RM4000, there is no respondent.

\section{Mean, Standard deviation and Level of Variables}

Table 3: Mean of Variables and Level of Factors Consumer Behaviour (Attitude, Brand Awareness, Consumer Experience, Price) and Female Purchase Intention with Standard Deviation

\begin{tabular}{llcccc}
\hline \multicolumn{1}{c}{ Variable } & \multicolumn{1}{c}{ Dimension } & $\begin{array}{c}\text { No. of } \\
\text { Items }\end{array}$ & Mean & $\begin{array}{c}\text { Std. } \\
\text { Dev. }\end{array}$ & Level \\
\hline $\begin{array}{l}\text { Independent } \\
\text { variable }\end{array}$ & a. Attitude & 8 & 3.67 & 1.16 & Very Good \\
\cline { 2 - 6 } & b. Brand Awareness & 6 & 3.81 & 1.31 & Very Good \\
\cline { 2 - 6 } & c. Consumer & 6 & 3.79 & 1.19 & Very Good \\
& $\quad$ Experience & 6 & 4.04 & 1.25 & Very Good \\
\cline { 2 - 6 } & d. Price & 5 & 3.61 & 1.18 & Good \\
\hline $\begin{array}{l}\text { Dependent } \\
\text { variable }\end{array}$ & Female Purchase Intention & & & & \\
\hline $\begin{array}{l}\text { (N=226); Range is based on Likert Scale of 1 to 5 where 1.00-2.33=Low; 2.34-3.66= Good; 3.67-5.00=Very } \\
\text { Good } \\
\text { Copyright } \odot \text { GLOBAL ACADEMIC EXCELLENCE (M) SDN BHD - All rights reserved }\end{array}$ & & & \\
\end{tabular}


The level of attitude, brand awareness, consumer experience and price tabulated in Table 3 shows at very good level. While, female purchase intention range at good level. However, the highest mean in independent variable is 4.04 for price and the lowest mean is attitude (3.67). For standard deviation, the highest is brand awareness (1.31) and the lowest is attitude (1.16).

\section{Pearson's Correlation Analysis}

Table 4: Correlation Analysis

\begin{tabular}{cccccc}
\hline Hypothesis & Relationship & $\boldsymbol{r}$ & P-value & $\begin{array}{c}\text { Sig. } \\
\text { Level }\end{array}$ & Decision \\
\hline $\mathbf{H}_{\mathbf{1}}$ & A->FPI & 0.81 & 0.000 & $* *$ & Supported \\
$\mathbf{H}_{2}$ & BA->FPI & 0.67 & 0.000 & $* *$ & Supported \\
$\mathbf{H}_{3}$ & CE->FPI & 0.78 & 0.000 & $* *$ & Supported \\
$\mathbf{H}_{\mathbf{4}}$ & P->FPI & 0.71 & 0.000 & $* *$ & Supported \\
\hline
\end{tabular}

Note: **Significant at 0.001 level; A=Attitude; BA=Brand Awareness; $C E=$ Consumer Experience; P=Price; FPI=Female Purchase Intention

Based on the Table 4 above, the p-value of attitude, brand awareness, consumer experience, and price are $0.000<0.001$. Besides, the correlation coefficient ( $r$-value) of attitude, consumer experience, and price showed a result $0.81,0.78$ and 0.71 high positive relationships among independent variable respectively while brand awareness is 0.67 have a moderate positive relationship. Hence, hypothesis $\mathrm{H}_{1}, \mathrm{H}_{2}, \mathrm{H}_{3}$ and $\mathrm{H}_{4}$ was accepted a significant influences relationship between attitude, brand awareness, consumer experience, price and women purchase intention towards local cosmetic product. Thus, $\mathrm{H}_{0}$ is rejected.

\section{Model Summary}

Table 5: The Effect of Consumer Behaviour on Female Purchase Intention

\begin{tabular}{lc}
\hline Independent Variables & Beta standardized \\
\cline { 2 - 2 } Model variables & Model \\
\hline Brand Awareness & 0.10 \\
\hline Consumer Experience & $0.24 * * *$ \\
\hline Price & $0.24 * * *$ \\
\hline Attitude & $0.40^{* * *}$ \\
\hline $\mathrm{R}^{2}$ & 0.76 \\
\hline Adj. $\mathrm{R}^{2}$ & 0.75 \\
\hline $\mathrm{R}^{2}$ Change & 0.004 \\
\hline F Change & $4.037 * * *$ \\
\hline Note: $* * *$ Sig.at.001 &
\end{tabular}

Table 5 tabulates the model summary of predicting the statistical relationship and describe the relationship between consumer behaviour (attitude, brand awareness, consumer experience, price) and female purchase intention towards local cosmetic product. The coefficient of determination is measure of the amount of variance in dependent variable explained by the dependent variables. The value of 0.76 indicates that $76 \%$ of the variance in the female purchase intention (dependent variable) is explained by four consumer behaviour factors. Brand awareness with standardized coefficient of 0.10 is an insignificant because at $p>0.001$. 
However, consumer experience and price with same value of 0.24 is significant at $p<0.001$ and attitude with value of 0.40 are significantly contributing to the variance explained. The $F$ change value of $p<0.001$ indicates variance was significantly explained by model.

\section{Discussions and Recommendations}

Overall of the result show that the relationship between each of independent variable and dependent variable that determine purchase intention among young female consumer in Universiti Malaysia Kelantan.

Attitude show the most positive factors to women purchase intention towards local cosmetics. Based on Multiple Linear Regression, attitude showed a result $\beta=0.41, p<0.001$. Hypothesis $\left(\mathrm{H}_{1}\right)$ was accepted as there was a significant influences relationship between attitude and women purchase intention towards local product. The Pearson correlation for the relationship is 0.81 or $81.00 \%$ that indicate the negotiation have a high strong positive linear in relationship. Attitude is the most part thought to be the fundamental intention in purchasing local cosmetic product. According to Ying San et al., (2012) consumers' attitudes are developed from personal experiences, earning with reality, information from friends and salesperson. Usually the consumer's knowledge about the ingredients used in local cosmetic product will effect on their attitude. The result also shows that attitude towards their dependent variable. Based on the result, respondent is mostly agreed with the attitude when they have purchase intention to select the local cosmetic product.

Besides, it shows that consumer experiences give the positive factors to female purchase intention towards local cosmetics. From the Multiple Linear Regression analyses, brand awareness showed a result $\beta=0.22, \mathrm{p}<0.001$. Hypothesis $\left(\mathrm{H}_{1}\right)$ was accepted as there was a significant relationship between consumer experiences and female purchase intention towards local product. The Pearson correlation for the relationship is 0.78 or $78.00 \%$ that indicate the negotiation have a high strong positive linear correlation in relationship. They have significant relationship between the consumer experiences and female purchase intention. Consumer experiences factors has influences purchase intention, this was supported by previous study that the more positive the person's past experience, the more positive their attitude and more likely they are to engage in the online environment (Ying San et al., 2012). In past reviews, consumer establish the progression of the experience based on specific goals and achieve customer satisfaction with the experience (Puccinelli et al., 2009).

Other than that, price also gives the positive factors to women purchase intention towards local cosmetics. From the analyses of Multiple Linear Regression, price showed a result $\beta=0.23, p$ $<0.001$. Hypothesis $\left(\mathrm{H}_{1}\right)$ was accepted as there was a significant relationship between brand awareness and women purchase intention towards local product. The Pearson correlation for the relationship is 0.71 or $71.00 \%$ that indicate the negotiation have a high strong positive linear correlation in relationship. They have significant relationship between the brand awareness and women purchase intention. Besides that, the research conducted by Chin \& Harizan (2017). These findings support the early studies of because price is considered important in forming price perceptions that later affect the behavioural intentions in purchasing. However, purchase intention changes associated with different price levels will be higher for subjects who are familiar with the products than for subjects who are less familiar with the products (Harlam, Krishna, Lehmann, \& Mela, 1995).

However, this research gives implication to female consumer who is wearing a local cosmetic product in their daily life. The information gathered in this research will give explanation about 
the local cosmetics product to them to avoid feeling worried or confused when using the cosmetics. This research will make female consumer became more alert and aware about the cosmetics they buy and wear to avoid from bad or worse effect to their skin. Besides, this study also contributes an industry or organization who involve in produce local cosmetic product. The industry must produce a cosmetic product which safe and effective when use it. This research will make the industry to be more focuses on standard which satisfy customer needs and wants from local cosmetics product. At the same time, it can increase the company profit. Lastly, this study can be a guideline for the retailer who sale a local cosmetic product to be more alert on what kind of product a customer finds from local cosmetics product. The findings will be helped in providing necessary information to guide the retailers before they sale the local cosmetics product to consumer. It will assist to extract lesson to retailer according research issues which have the potential affect their business.

Besides, for future study, the researcher suggested to do a research about the online purchases intention. This is because, nowadays, there a lot of local cosmetic products are selling online by seller without exposure of clean and originality of products. Since nowadays there is lack of research on online platform and retailers are assume that online platform can help them to viral and boost their sales, researcher have to do a research about online purchases intention. The researcher can add more independent variable such as feedback, product performance and product packaging into the research so that we can know more about what the online purchases intention of local cosmetic products are. Furthermore, through this research, it can help online retailer to upgrade their products and understand their target customer.

\section{Conclusion}

The purpose of this study is to identify the factors that influence female purchase intention toward local cosmetic product. This study had underlined four objectives to be achieved in this research. As a conclusion, the overall study has been discussed by identified and the findings of the data collected. After running the Multiple Linear Regression, attitude, consumer experience and price had shown a significant relationship with female purchase intention toward local cosmetic product. However, only brand awareness had shown insignificant relationship with female purchase intention toward local cosmetic product. The finding had also shown that attitude was the most significant factor that contributed to female purchase intention toward local cosmetic product. During the research progress, this study had discussed about the limitation that had been encountered and the recommendation for future researchers. The findings were expected to provide insight and knowledge of factors that influence female purchase intention toward local cosmetic product for the respondents, retailers and also future researchers.

\section{References}

Andrews, D. F. (1974). A robust method for multiple linear regression. Technometrics, 16(4), 523-531. https://doi.org/10.1080/00401706.1974.10489233

Arnold, D. M., Burns, K. E. A., Adhikari, N. K. J., Kho, M. E., Meade, M. O., \& Cook, D. J. (2009). The design and interpretation of pilot trials in clinical research in critical care. Critical Care Medicine, 37(1), 69-74. https://doi.org/10.1097/CCM.0b013e3181920e33

Azmi Hassali, M., \& AL-Tamimi, S. K. (2015). Malaysian Cosmetic Market: Current and Future Prospects. Pharmaceutical Regulatory Affairs: Open Access, 04(04), 10-13. https://doi.org/10.4172/2167-7689.1000155 
Belleau, B. D., Summers, T. A., Xu, Y., \& Pinel, R. (2007a). Theory of reasoned action: Purchase intention of young consumers. Clothing and Textiles Research Journal. https://doi.org/10.1177/0887302X07302768

Belleau, B. D., Summers, T. A., Xu, Y., \& Pinel, R. (2007b). Theory of reasoned action: Purchase intention of young consumers. Clothing and Textiles Research Journal, 25(3), 244-257. https://doi.org/10.1177/0887302X07302768

Borzooei, Mahdi, M. A., \& Asgari, M. (2013). Halal Branding and Purchase Intention : A Brand Personality Appeal Perspective. International Journal of Business and Management Invention, 2(8), 23-27. https://doi.org/ISSN (Online): 2319 - 8028

Bouranta, N., Chitiris, L., \& Paravantis, J. (2009). The relationship between internal and external service quality. International Journal of Contemporary Hospitality Management, 21(3), 275-293. https://doi.org/10.1108/09596110910948297

Branston, N. M., Symon, L., \& Strong, A. J. (2003). Reversibility of ischaemically induced changes in extracellular potassium in primate cortex. Journal of the Neurological Sciences, 37(1-2), 37-49. https://doi.org/10.1016/0022-510X(78)90226-5

Brown, M., Pope, N., \& Voges, K. (2003). Buying or browsing? European Journal of Marketing, 37(11/12), 1666-1684. https://doi.org/10.1108/03090560310495401

Chin, T. K., \& Harizan, S. H. M. (2017). Factors Influencing Consumers' Purchase Intention of Cosmetic Products in Malaysia. International Journal of Business and Innovation, 3(1), 15. https://doi.org/10.1186/s40691-017-0091-3

D’Souza, C., Taghian, M., \& Khosla, R. (2007). Examination of environmental beliefs and its impact on the influence of price, quality and demographic characteristics with respect to green purchase intention. Journal of Targeting, Measurement and Analysis for Marketing, 15(2), 69-78. https://doi.org/10.1057/palgrave.jt.5750039

Eze, U. C., Tan, C.-B., \& Yeo, A. L.-Y. (2012). Purchasing Cosmetic Products: A Preliminary Perspective of Gen-Y. Contemporary Management Research, 8(1), 51-60. https://doi.org/10.7903/cmr.10149

Eze, U. C., \& Tan, C. (2012). Purchasing Cosmetic Products : A Preliminary Perspective of, $8(1), 51-60$.

Gliem, J. A., \& Gliem, R. R. (2003). Calculating, Interpreting, and Reporting Cronbach 's Alpha Reliability Coefficient for Likert-Type Scales, (1992), 82-88. https://doi.org/10.1109/PROC.1975.9792

Grewal, D., Monroe, K. B., \& Krishnan, R. (1998). The Effects of Price-Comparison Advertising on Buyers' Perceptions of Acquisition Value, Transaction Value, and Behavioral Intentions. Journal of Marketing, 62(2), 46. https://doi.org/10.2307/1252160

Hair, J.F., Babin, B., Money, A.H., \& Samouel, P. (2001). Essential of business research method. USA: John Wiley \& Sonc Inc.

Harlam, B. A., Krishna, A., Lehmann, D. R., \& Mela, C. (1995). Impact of bundle type, price framing and familiarity on purchase intention for the bundle. Journal of Business Research, 33(1), 57-66. https://doi.org/10.1016/0148-2963(94)00014-6

Hashim, P., \& Mat Hashim, D. (2013). Review of Cosmetic and Personal Care Products : Halal Perspective and Detection of Ingredient. Science \& Technology, 21(2), 281-292.

Hassali, M. A., Al-tamimi, S., Dawood, O. T., \& Verma, A. K. (2015). Malaysian cosmetic market : current and future prospects Pharmaceutical regulatory affairs : Open access malaysian cosmetic market: current and future prospects, (October), 10-13. https://doi.org/10.4172/2167-7689.1000155

Ilicic, J., \& Webster, C. M. (2011). Effects of multiple endorsements and consumer - celebrity attachment on attitude and purchase intention. Australasian Marketing Journal (AMJ), 19(4), 230-237. https://doi.org/10.1016/j.ausmj.2011.07.005 
Jr, S. L. S., Omar, M. W., \& Wahid, N. A. (2007). THE EFFECT OF BRAND IMAGE ON OVERALL SATISFACTION AND LOYALTY INTENTION IN THE CONTEXT OF COLOR COSMETIC, 12(1), 83-107.

Kenyon, G., \& Sen, K. (2012). A model for assessing consumer perceptions of quality. International Journal of Quality and Service Sciences, 4(2), 175-188. https://doi.org/10.1108/17566691211232909

Krejcie, R. V, \& Morgan, D. (1970). Determining sample size for research activities. Education and Psrchological Measurement, 30(3), 607-610.

Krishnan, S., Amira, N. S., Atilla, U. N., Syafawan, S., \& Hafiz, M. (2017). The Usage of Cosmetic in Malaysia: Understanding the Major Factors that Affect the Users. Scientific \& Academic Publishing, 7(1), 48-51. https://doi.org/10.5923/j.mm.20170701.07

Lada, S., Harvey Tanakinjal, G., \& Amin, H. (2009). Predicting intention to choose halal products using theory of reasoned action. International Journal of Islamic and Middle Eastern Finance and Management, 2(1), 66-76. https://doi.org/10.1108/17538390910946276

Larasati, S. (2013). Factors Affecting Consumer Decision-. Transactions on Industrial, Financial \& Business Management, 1(5), 175-180.

Ling, K. C., Chai, L. T., \& Piew, T. H. (2010). The Effects of Shopping Orientations, Online Trust and Prior Online Purchase Experience toward Customers' Online Purchase Intention. International Business Research, 3(3), 63. https://doi.org/10.5539/ibr.v3n3p63

M Reiners, G. (2012). Understanding the Differences between Husserl's (Descriptive) and Heidegger's (Interpretive) Phenomenological Research. Journal of Nursing \& Care, 01(05), 1-3. https://doi.org/10.4172/2167-1168.1000119

Mahdi, B., \& Maryam, A. (2013). The Halal brand personality and its effect on purchase intention Mahdi Borzooei and Maryam Asgari Business Management Faculty ,. Interdisciplinary Journal of Contemporary Reserach in Business, (May 2014), 481491. https://doi.org/10.1364/OE.25.006904

Mansor, N., \& Yaacob, M. R. (2010). Cosmetic Usage in Malaysia: Understanding of the Major Determinants Affecting the Users Faculty of Business Management. International Journal of Business and Social Science, 1(3), 273-281.

Moon, J., Chadee, D., \& Tikoo, S. (2008). 2008 - Culture, product type, and price influences on consumer purchase intention to buy personalized products online - Moon, Chadee, Tikoo.pdf. Journal of Business Research, 61(1), 31-39.

Oh, H. (2000). The Effect of Brand Class, Brand Awareness, and Price on Customer Value and Behavioral Intentions. Journal of Hospitality and Tourism Research, 24(2), 136-162. https://doi.org/10.1177/109634800002400202

Park, M., \& Lennon, S. J. (2009). Brand name and promotion in online shopping contexts. Journal of Fashion Marketing and Management: An International Journal, 13(2), 149160. https://doi.org/10.1108/13612020910957680

Peterson, R. A. (2013). Meta-analysis of Alpha Cronbach' s Coefficient. Journal of Consumer Research, 21(2), 381-391. https://doi.org/10.1093/bioinformatics/btr476

Puccinelli, N. M., Goodstein, R. C., Grewal, D., Price, R., Raghubir, P., \& Stewart, D. (2009). Customer Experience Management in Retailing: Understanding the Buying Process. Journal of Retailing, 85(1), 15-30. https://doi.org/10.1016/j.jretai.2008.11.003

Rahim, M. A. (2018). THE FACTORS THAT INFLUENCE THE CONSUMPTION OF LOCAL COSMETIC PRODUCTS AMONG CONSUMERS IN KOTA BHARU ,. Business and Management, ISBN: 978-(January). 
Rezvani, S., Dehkordi, G. J., Rahman, M. S., Fouladivanda, F., Habibi, M., \& Eghtebasi, S. (2012). A conceptual study on the country of origin effect on consumer purchase intention. Asian Social Science, 8(12), 205-215. https://doi.org/10.5539/ass.v8n12p205

Singh, A., \& Bansal, D. (2016). A comparative study of consumer perception of product quality: Chinese products versus nonchinese product. International Journal of Economic Research, 13(1), 445-458. https://doi.org/10.1016/j.sbspro.2014.04.005

Singh, P., \& Pattanayak, J. (2014). Linking of Customer Satisfaction with Shareholders' value: A Review. Global Journal of Finance and ..., 6(5), 403-412. Retrieved from http://www.ripublication.com/gjfm-spl/gjfmv6n5_03.pdf

Steenkamp, J.-B. E. M., \& de Jong, M. G. (2010). A Global Investigation into the Constellation of Consumer Attitudes Toward Global and Local Products. Journal of Marketing, 74(6), 18-40. https://doi.org/10.1509/jmkg.74.6.18

Whiltar, D. B., Geurts, M. D., \& Swenson, M. J. (1993). New product forecasting with a purchase intention survey. The Journal of Business Forecasting Methods Systems and Systems. The Journal of Business Forecasting Methods \& Systems, 12(3), 1-18.

Yee, W. F., \& Sidek, Y. (2008). Influence of Brand Loyalty on Consumer Satisfaction Towards Sportswear. International Journal of Economics and Management, 2(2), 221-236. https://doi.org/10.5539/ijms.v3n2p123

Yeo, B. L., Mohamed, R. H. N., \& Muda, M. (2016). A Study of Malaysian Customers Purchase Motivation of Halal Cosmetics Retail Products: Examining Theory of Consumption Value and Customer Satisfaction. Procedia Economics and Finance, 37(16), 176-182. https://doi.org/10.1016/S2212-5671(16)30110-1

Ying San, L. I. M., Yuan Sim, T. E. O., Christine Nya Ling, T. A. N., \& Tuan Hock, N. G. (2012). Cosmetic product: A study of Malaysian women shoppers in cyberspace. World Applied Sciences Journal, 20(11), 1529-1533. https://doi.org/10.5829/idosi.wasj.2012.20.11.1623 